\title{
Üniversite Öğrencilerinin İnternet Tabanlı Akademik Usulsüzlük Nedenlerinin Çeşitli Değişkenlere Göre İncelenmesi
}

\author{
Feza ORHAN* $\quad$ Ayşe GÜNAY ${ }^{* *}$
}

\section{$\ddot{O} z$}

Günlük hayatı ve akademik çalışmaları oldukça kolaylaştıran internet, beraberinde web sitelerinden indirilebilen ödevler, kopyala- yapıştır özellikleri sunması ve sınırsız usulsüzlüklere olanak sağlama özelliği ile de öğretim sürecinde ilgilenilmesi gereken bir sorun haline gelmiştir. Öğrencilerin intihal yapmalarını önlemek için her şeyden önce bu davranışlarının nedenlerini anlamak ve bu yönde çözümler geliştirmek etkili bir yol olabilir. Bu araştırmada, farklı fakültelerde öğrenim gören ve kolay ulaşılabilir örnekleme yöntemi ile oluşturulan 524 öğrencinin ödev ve projelerinde internetten aşırma davranışında bulunma nedenlerine ilişkin görüşleri, yaş cinsiyet ve fakülte değişkenlerine göre incelenmektedir Betimsel nitelikli bu araştırmada veriler araştırmacılar tarafından geliştirilen anket ile toplanmıştır. Verilerin analizinde yüzde-frekans, aritmetik ortalama, standart sapma, t-testi, tek yönlü varyans analizi (ANOVA) ve Tukey testi kullanılmıştır. Araştırmanın bulgularına göre, Yıldız Teknik Üniversitesi öğrencileri ile gerçekleştirilen bu çalışmada öğrencileri internetten akademik usulsüzlüğe iten nedenler verilen ödevlerin niteliği, değerlendirme yöntemi, öğrencilerin derse karşı duyuşsal yaklaşımı ve öğrencilerin ödev yapmadaki zaman yönetimi açısından cinsiyet, fakülte ve sınıf düzeyine göre istatistiksel olarak anlamlı farklılık göstermektedir.

Anahtar kelimeler: Etik, internet, intihal, e- usulsüzlük, akademik usulsüzlük

\footnotetext{
${ }^{*}$ Doç. Dr., Yıldız Teknik Üniversitesi Eğitim Fakültesi, feza.orhan@gmail.com

** Ar. Gör., Yıldız Teknik Üniversitesi Eğitim Fakültesi, aysegunayse@ gmail.com
} 


\title{
Internet Based Academic Dishonesty of the University Students
}

\section{in terms of Grade Level, Gender and Faculty}

\begin{abstract}
While internet facilitates the daily life and academic studies in terms of websites with downloadable assignments and copy and paste features, it provides unlimited irregularities features has become a problem that must be tackled in the teaching and learning process. In order to prevent the academic dishonesty of the students, first of all we have to understand the reasons of this behavior can be an effective way to develop solutions in this direction. In this research, the opinions of the 524 students from different faculties are examined about plagiarism from the internet by taking age, gender and faculty variables into consideration. Data were collected by a questionnaire develop by the researchers in this descriptive study. Percent- frequency, arithmetic mean, standard deviation, $t$-test, one- way analysis of variance (ANOVA) and Tukey test are used in the analysis of the data. According to the findings of the study, the reasons of the academic dishonesty from the internet has emerged as the quality of the homework, evaluation method of the instructor, students' affective approach towards to the lesson and time management that shows statistically differences in terms of grade level, gender and faculty.
\end{abstract}

Keywords: Ethic, internet, academic dishonesty, e-dishonesty 



\section{Giriş}

1222 üniversite öğrencisinin interneti kullanma amaçlarının incelendiği bir çalışmada, "ödev hazırlama ve akademik çalışma" için internet kullanımının sıklık oranı $\% 50$ ortalama ile öğrencilerin interneti en çok kullanma nedenlerinden biri olarak saptanmıştır (Selwyn, 2008). Türkiye'de 687 üniversite öğrencisi üzerinde yapılan bir araştırmada da öğrencilerin \%62,8'inin interneti ödev ve dersle ilgili araştırma yapmak için kullandıklarını belirtmişlerdir (Okay ve Aydoğan, 2010). Ancak, diğer taraftan günlük hayatı ve akademik çalışmaları oldukça kolaylaştıran internet, beraberinde web sitelerinden kolayca indirilebilen ödevler, kopyala- yapıştır imkanıyla sınırsız usulsüzlüklere olanak sağlama özelliği ile de eğitim ve öğretimde ilgilenilmesi gereken bir sorun haline gelmiştir.

İntihal (TDK: Aşırma), bir kişinin eserinde başka kişilerin ifade, buluş veya düşüncelerini kaynak göstermeksizin kendisine aitmiş gibi kullanmasıdır. İntihal bir tür sahtekârlık ve hırsızlıktır. Internet ve bilgisayar teknolojileri, dosyaları kolayca indirebilme, kopyala- yapıştır aracı ve bilgi kaynaklarına erişimde sağladığı kolay ulaşılabilirlik ile kopyacılığı, yani akademik usulsüzlüğü yaygınlaştırmıştır (Karim, Zamzuri, ve Nor, 2009). Kelime işlemci programlarının elverişli fonksiyonları, fikirleri ve bilgileri internetten veya diğer elektronik medyalardan kolayca kopyalayıp yapıştırmayı sağlayan özellikleri öğrencilerin akademik usulsüzlüğe meyletmelerine neden olmaktadır (Austin ve Brown, 1999). Sitelerin herhangi bir uyarı veya onay butonu eklememeleri, usulsüzlüğe yeltenen öğrenciler için hiçbir uyarıda bulunmamaları, tam aksine çalışmalara ulaşabilmeleri için bedava üyelik, konulara, okula ve hatta öğretmenlere göre kategorize edilmiş ödevleri indirme imkanı, yeni bir konu hakkında ödev yüklendiğinde ve sitedeki konuların güncellemesinde e-posta gönderimi vb. hizmetler öğrencilerin akademik usulsüzlüğe daha fazla yeltenmelerine yol açmaktadır. Öğrenciler zahmetsizce aradıkları konuya erişebilmektedirler (Renard, 2000). Aşırma yapmak ne kadar kolaylaşırsa öğrencilerin buna yönelme eğilimi de o kadar artmaktadır. (Davis, Drinan ve Gallant , 2009).

Araştırmalar öğrencilerin akademik usulsüzlük yapmalarının birçok sebebinin olduğunu göstermektedir. Davis vd. (2009) özellikle üniversite öğrencilerinin mezun olduklarında daha iyi bir işe, lise öğrencilerinin ise daha prestijli bir üniversiteye girme isteğinin akademik usulsüzlüğe yönelten önemli sebepler arasında olduğunu ve bunun da parlak not almaktan geçtiğini düşündükleri için kimi durumlarda veya her durumda öğrencilerin akademik usulsüzlük davranışlarını sergilediklerini belirtmiş̧ir. Haines, Diekhoff, LaBeff, ve Clark (1986) yaptıkları bir araştırmanın sonuçlarına dayalı olarak öğrencilerin 
akademik usulsüzlüğü tüm arkadaşlarının yaptığını, bu durumun da aşırma yapma konusunda onları cesaretlendirdiğini ve bir süre sonra aşırmanın normal göründüğünü söylemişlerdir. Uzun sürecek ödevlerin aşırma ile çok daha kısa sürede halledilebilecek olması, öğrencilerin okul dışında da çalışmak zorunda olmaları ve bu yüzden de zaman sıkıntısı yaşamaları (Roig, 2006; Davis vd., 2009), derste işlenen konularla ilgili öğrencilerin fikirlerini ön plana çıkarmayan, ezbere dayalı bir değerlendirme yöntemi içeren ödevler verilmesi (Khodaie, Moghadamzadeh, ve Salehi, 2011) öğrencileri akademik usulsüzlüğe iten nedenler olarak ortaya çıkmaktadır. Henüz İnternet'in olmadığ 1938 tarihli bir çalışmasında Ludemann (1938) verilen ödevin çok kolay, çok zor ya da anlamsız olmasının da öğrencileri aşırmaya iteceğini belirtmiştir. Öğretim elemanının verdiği ödevin kaynaklarını kontrol edeceğini söylemesi, internetten kopya ödev yapanlara çeşitli yaptırımlarda bulunacağını dile getirmesi öğretmen adayı öğrencilerin internetten intihal yapma eğilimlerini azaltacağ1 ortaya çıkmıştır (Ersoy ve Özden, 2011). Bu durum öğrencilerin kontrol edilecek olmasının, internetten aşırma yapma davranışını kontrol altına almada etkili olacağını göstermektedir.

Yapılan araştırmalarda erkeklerin kadınlara oranla akademik usulsüzlüğe daha fazla meyilli oldukları ortaya çıkmıştır (Kelly ve Worrell, 1978). 1960'larda yapılan araştırmalar da erkeklerin kadınlara göre daha fazla akademik usulsüzlük yaptığını ortaya koymaktadır (Bowers, 1964; Roskens ve Dizney, 1966). Fakat 1980 'li yıllarda yapılan çalışmalar kadınların erkeklerden daha fazla akademik usulsüzlükte bulunduklarını göstermektedir (Lerning, 1980; Antonio ve Michael, 1983). Ward ve Beck (1990) kadınların erkeklerden daha az akademik usulsüzlük yapıyor olmasını "Sex Role Socialization Theory" ile açılamışlardır. Bu teoriye göre kadınlar sosyalleşmek adına kurallara daha çok itaat etmeye meyillidirler.

Öğrencinin yanlış bölüm seçimi ile akademik usulsüzlüğe eğilimi arasında doğrudan bir ilişki bulunmaktadır (Prenshaw, Straughan, ve Albers-Miller, 2001). Bu tip öğrenciler üniversite eğitimine idealist bir şekilde yaklaşmayan, üniversiteyi yapılması gereken bir iş gibi gören ve sadece mezun olduklarında alacakları bir kağıt parçasıyla iş dünyasına atılabilecekleri bir köprü olarak görmektedirler. Davis vd. (2009) ve Roig (2006) bu tip öğrencileri üniversite eğitimini öğrenmenin gerçekleştiği bir yer olarak değil, diploma edinme kurumu olarak gören, genel ortalama odaklı öğrenciler olarak tanımlamakta ve akademik usulsüzlüğe daha meyilli olduklarını ileri sürmektedirler.

Albers-Miller, Straughan ve Prenshaw (2000) yaş ile akademik usulsüzlük arasında ters ilişki bulmuştur; yaş arttıkça akademik usulsüzlük oranı 
azalmaktadır. Bu durum 1980'lerde gerçekleştirilen araştırmalarda da benzerlik göstermektedir: daha genç olan öğrenciler, yaşları ilerlemiş öğrencilere göre daha fazla akademik usulsüzlük yapmaktadır (Antonio ve Michael, 1983; Haines, Diekhoff, LaBeff, ve Clark, 1986).

$\mathrm{Bu}$ vb. araştırma sonuçları ve üniversitelerde görevli öğretim elemanlarının öğrencilerin akademik usulsüzlüklerinden çokça şikayet etmeleri araştırmacıları, üniversite öğrencilerinin durumunu araştırmaya yönlendirmiştir. Bu nedenle bu çalışmada, öğrencilerin akademik usulsüzlük yapmalarını önlemek için her şeyden önce bu davranışlarının nedenlerini anlamak ve bu yönde çözümler geliştirmek gerektiği bakış açısından yola çıkılarak üç temel soruya cevap aranmıştır:

Üniversite öğrencilerinin Verilen Ödevlerin Niteliği ve Değerlendirme Yöntemi nedeni ile akademik usulsüzlüğe iten nedenler ile ilgili görüşleri nelerdir ve cinsiyet, fakülte, sınıf düzeyi değişkenine göre anlamlı farklılık göstermekte midir?

Üniversite öğrencilerinin Derse Karşı Duyuşsal Tutumu nedeni ile akademik usulsüzlüğe iten nedenler ile ilgili görüşleri nelerdir ve cinsiyet, fakülte, sinıf düzeyi değişkenine göre anlamlı farklılık göstermekte midir?

Üniversite öğrencilerinin Zaman Yönetimi nedeni ile akademik usulsüzlüğe iten nedenler ile ilgili görüşleri nelerdir ve cinsiyet, fakülte, sınıf düzeyi değişkenine göre anlamlı farklllık göstermekte midir?

\section{Yöntem}

\section{1. Çalışma Grubu}

Araştırmanın çalışma grubunu Yıldız Teknik Üniversitesi'nde (YTÜ) farklı fakültelerde (Eğitim Fakültesi, Makina Fakültesi, Elektrik-Elektronik Fakültesi, İnşaat Fakültesi, Kimya- Metalurji Fakültesi, Fen- Edebiyat Fakültesi ve İktisadi ve İdari Bilimler) 2011-2012 yıllarında okuyan 524 öğrenci oluşturmaktadır. Öğrenci sayılarının ve fakültelerin dağılımları Tablo 1'de görülmektedir.

Tablo 1. Çalışma grubu profili

\begin{tabular}{llcc}
\hline & & $\begin{array}{c}\text { Freka } \\
\text { ns }\end{array}$ & $\begin{array}{c}\text { Yüzde } \\
(\mathbf{\%})\end{array}$ \\
\hline Cinsiyet & Kadın & 233 & 44.5 \\
& Erkek & 291 & 55.5 \\
\hline Bölüm & Eğitim Fakültesi & 107 & 20.4 \\
& Makina Fakültesi & 95 & 18.1 \\
& Elektrik- Elektronik & 83 & 15.8 \\
& Fakültesi & 24 & 4.6 \\
& İnşaat Fakültesi & 72 & 13.7 \\
& Kimya Metalurji & 96 & 18.3 \\
& Fakültesi & 47 & 9 \\
& Fen- Edebiyat Fakültesi & 96 & $\mathbf{1 0 0}$ \\
& İdari İktisadi Bilimler & 4 &
\end{tabular}




\subsection{Veri Toplama Aracı}

Çalışmanın ilk boyutunda 25 son sınıf öğrencisi ile yüz yüze görüşme yapılarak dört yıllık öğretim hayatlarında hepsinin ama ufak ama büyük internetten aşırma yaptıkları tespit edilmiş ve öğrencilerle yüz yüze tartışılarak onları bu davranışa iten nedenler tespit edilmiştir. Bu görüşmeden elde edilen bilgiler ve incelenen literatür doğrultusunda araştırmacılar tarafından bu çalışmada kullanılmak üzere Akademik Usulsüzlüğe İten Nedenler İle İlgili Görüş Anketi geliştirilmiştir. Anket toplam 11 önermeden oluşmaktadır. Faktör analizi sonucunda ölçekte 3 faktör ortaya çıkmıştır. İlk boyut öğrencilerin Verilen Ödevlerin Niteliği ve Değerlendirme Yöntemi ile ilgili görüşlerini; ikinci boyut Verilen Ödevlerin Yararına İnanma ile ilgili görüşlerini; üçüncü boyut Zaman Yönetimi ile ilgili görüşlerini ölçmektedir. Anketin kapsam geçerliliğgi YTÜ'de görev yapan 4 öğretim elemanı ve 10 öğrenci tarafından incelenmiş ve uygun bulunmuştur. Anketin bütününe yönelik iç tutarlllık güvenirlik düzeyi 0.700 'dür. Anket elektronik ortamda akademik usulsüzlük yaptığını kabul eden öğrenciler tarafından doldurulmuştur.

\subsection{Veri Analizi}

Elde edilen verilerin analizinde IBM SPSS 20.0 programı kullanılmıştır. Verilerin analizinde yüzde-frekans, aritmetik ortalama, standart sapma, t- testi, tek yönlü varyans analiz (ANOVA) ve Tukey testi kullanılmıştır.

\section{Bulgular ve Yorum}

Bulgu ve yorumlar araştırma sorusu bazında sunulmuştur.

\section{Birinci Araştırma Sorusu İle İlgili Bulgular ve Yorumlar}

Üniversite öğrencilerinin Verilen Ödevlerin Niteliği ve Değerlendirme Yöntemi nedeni ile akademik usulsüzlüğe iten nedenler ile ilgili görüşlerinin neler olduğuna yönelik bulgular Tablo 2'de verilmiştir. Görüşlerini etkileyecek değişkenlerden biri olan cinsiyet için bağımsız gruplar $t$ testi yapılmış, görüşlerini etkileyebilecek bir diğer değişken olan okudukları fakülte, sınıf düzeyi için ise Anova testi yapılmıştır. 
Tablo 2. Verilen ödevlerin niteliği ve değerlendirme yöntemi

\begin{tabular}{|c|c|c|c|c|c|c|}
\hline Sorular ve Faktörler & \multicolumn{2}{|c|}{ Katıliyorum } & \multicolumn{2}{|c|}{ NKNK } & \multicolumn{2}{|c|}{$\begin{array}{l}\text { Katilmiyoru } \\
\mathrm{m}\end{array}$} \\
\hline $\begin{array}{l}\text { Faktör 1: Verilen Ödevlerin Niteliği ve } \\
\text { Değerlendirme Yöntemi }\end{array}$ & $f$ & $\%$ & $f$ & $\%$ & $f$ & $\%$ \\
\hline $\begin{array}{l}\text { 1.Öğretmenler ezbere dayalı, yaratıcılığı } \\
\text { olmayan ödevler veriyor. }\end{array}$ & 239 & 45,9 & 206 & 39,3 & 79 & 15,1 \\
\hline $\begin{array}{l}\text { 2.Verilen ödevler/projeler dersin kapsamiyla } \\
\text { uyuşmuyor. }\end{array}$ & 56 & 10,7 & 224 & 42,7 & 244 & 46,4 \\
\hline $\begin{array}{l}\text { 3.Öğretmenler her yıl aynı ödevi veriyor. } \\
\text { 4.Ders öğretmeni verilen ödevi/proievi zaten }\end{array}$ & 176 & 33,6 & 228 & 43,5 & 120 & 22,9 \\
\hline $\begin{array}{l}\text { okumuyor sadece şekilsel bakıyor ve } \\
\text { notlandırıyor. }\end{array}$ & 161 & 30,7 & 264 & 50,4 & 99 & 18,9 \\
\hline $\begin{array}{l}\text { 5.Öğretmen zaten dersten yüksek not vererek } \\
\text { herkesi geçiriyor. }\end{array}$ & 33 & 6,3 & 103 & 19,7 & 338 & 74,0 \\
\hline $\begin{array}{l}\text { 6.Öğretmen sadece tanıdığı öğrencilerin } \\
\text { ödevlerine/projelerine yüksek not veriyor. }\end{array}$ & 72 & 13,7 & 208 & 39,7 & 244 & 46,6 \\
\hline Genel Ortalama & & 23,5 & & 39,2 & & 37,3 \\
\hline
\end{tabular}

Tablo 2 'de yer alan bulgular incelendiğinde madde $1(\% 45,9)$ katılım oranı ile öğrencileri internetten aşırma yapmaya iten en yüksek neden olarak tespit edilmiştir. Madde $3(\% 33,6)$ ise bir sonraki neden olarak belirtilmiştir. Bu bulgular öğretim elemanlarının öğrencilere farklı, onları gerçekten araştırmaya yönlendiren, öğrenmelerine katkı sunacak ödevler vermediği biçiminde de yorumlanabilir. Ayrıca, birbirinin tekrarı olmayan ödevler verilmesi de öğrencilerin akademik usulsüzlük eğilimlerini azaltabilir. \%30,7 öğrenci de öğretim elemanlarının ödevlerini kendilerinin okumadıklarını düşündükleri için akademik usulsüzlük yaptıklarını belirtmeleri de dikkate alınması gereken bir bulgudur. Bulgularda en çok da "katılmıyorum" sütunu altında yer alan değerler dikkat çekmektedir. Ne yazık ki öğretim elemanlarının yaratıcı (\%15.1) ve her yıl farklı ödevler (22.9) verdiklerine ilaveten verilen ödevleri okuduklarına (18.9) inanan öğrenci oranı çok düşüktür.

Bulgular incelendiğinde, öğrencilerin Verilen Ödevlerin Niteliği ve Değerlendirme Yöntemi nedeniyle internetten aşırma yapma davranışı göstermeye eğilimleri açısından cinsiyete göre $(p>.025)$, okudukları fakülteye göre $(p<.246)$, sinıf düzeyine göre $(p<.309)$ istatistiksel olarak anlamlı bir farklılık bulunmamaktadır.

\section{İkinci Araştırma Sorusu İle İlgili Bulgular ve Yorumlar}

Üniversite öğrencilerini Derse Karşı Duyuşsal Tutum nedeni ile akademik usulsüzlüğe iten nedenler ile ilgili görüşlerinin neler olduğuna yönelik bulgular 
Tablo 3'te verilmiştir. Görüşlerini etkileyecek değişkenlerden biri olan cinsiyet için bağımsız gruplar $\mathrm{t}$ testi yapılmış bulgular Tablo 4'de, görüşlerini etkileyebilecek bir diğer değişken olan okudukları fakülte, sınıf düzeyi için Anova testi yapılmış ve bulgular Tablo 5'de verilmiştir.

Tablo 3. Derse karşı duyuşsal tutum

\begin{tabular}{|c|c|c|c|c|c|c|}
\hline Sorular ve Faktörler & \multicolumn{2}{|c|}{ Katıliyorum } & \multicolumn{2}{|c|}{ NKNK } & \multicolumn{2}{|c|}{ Katılmiyorum } \\
\hline $\begin{array}{lllll}\text { Faktör 2: Derse Karşı Duyuşsal } \\
\text { Tutum }\end{array}$ & $f$ & $\%$ & $f$ & $\%$ & $f$ & $\%$ \\
\hline $\begin{array}{l}7 \text { Sevilmeyen derslerin ödevlerini/ } \\
\text { projelerini yapmayı vakit kaybı } \\
\text { olarak gördüğüm için emek } \\
\text { harcamak istemiyorum }\end{array}$ & 256 & 48,9 & 182 & 34,7 & 86 & 16,4 \\
\hline $\begin{array}{l}8 \text { İşime yaramayacağını } \\
\text { düşündüğüm dersler için } \\
\text { ödev/proje yapmak vakit kaybı } \\
\text { oluyor. }\end{array}$ & 259 & 49,4 & 198 & 37,8 & 67 & 12,8 \\
\hline Genel Ortalama & & 49,15 & & 36,25 & & 14,6 \\
\hline
\end{tabular}

*NKNK: Ne katıllyorum ne katılmıyorum

Tablo 3'e göre öğrencilerin aldıkları derse karşı olan duyuşsal tutumlarının, akademik usulsüzlüğe yönelmelerine etkisi olduğu görülmektedir. Madde 7 $(\% 48,9)$ ve madde $8(\% 49,4)$ 'teki bulgulara göre sevmedikleri ve işlerine yaramayacağını düşündükleri derslerin ödev veya projeleri ile uğraşmak istemedikleri için aşırma yaparak çalışmalarını bir an önce bitirmek ve kurtulmak için internetten aşırma yapmaya başvurduklarını söyleyebiliriz.

Tablo 4. Öğrencilerin derse karşı duyuşsal tutum ile ilgili durumlarının cinsiyete göre t-testi sonuçları

\begin{tabular}{llcccc}
\hline & Cinsiyet & $\mathrm{N}$ & Ortalama & Std. Sapma & $\mathrm{p}$ \\
\hline \multirow{2}{*}{ Ödev Yarar1 } & $\mathrm{K}$ & 233 & 2,264 &, 6246 & \multirow{2}{*}{, 005} \\
& $\mathrm{E}$ & 291 & 2,411 &, 5623 & \\
\hline
\end{tabular}

Tablo 4'te yer alan bulgular incelendiğinde, öğrencilerin verilen ödevlerin veya projelerin kendilerine bir şey katmayacağını düşündükleri ve sevmedikleri dersin ödevlerini vakit kaybı olarak gördükleri zaman internetten akademik usulsüzlüğe yönelmelerinde cinsiyete göre $(p>.005)$ istatistiksel olarak anlamlı bir farklılık bulunmaktadır. Tablo 4'deki bulgulara göre, erkek öğrencilerin sevmedikleri ve işlerine yaramayacağını düşündükleri derslerin ödev veya projelerini yaparken kızlara oranla internetten daha fazla aşırma yapmaya 
eğilimlerinin ortaya çıkmıştır. Nitekim bu bulgu, Ward \& Beck'in (1990) kadınların erkeklerden daha az akademik usulsüzlük yapıyor olmasını açıladığı "Sex Role Socialization Theory" ile paralellik göstermektedir.

Tablo 5. Öğrencilerin derse karşı duyuşsal tutum ile ilgili durumlarının fakültelere göre ANOVA sonuçlar

\begin{tabular}{lccccc}
\hline Varyansın Kaynağı & $\begin{array}{c}\text { Kareler } \\
\text { Toplamı }\end{array}$ & $\mathrm{Sd}$ & $\begin{array}{l}\text { Karelerin } \\
\text { Ortalaması }\end{array}$ & $\mathrm{F}$ & $\mathrm{p}$ \\
\hline Gruplar Arası & 4,472 & 6 &, 745 & 2,135 & \\
Gruplar İçi & 180,507 & 517 &, 349 & &, 048 \\
Toplam & 184,979 & 523 & & & \\
\hline
\end{tabular}

Tablo 5'e göre öğrencilerin ödevin yararına ilişkin bakış açılarının internetten akademik usulsüzlük yapmaya olan yönelimlerini etkilemesinde fakültelere göre az da olsa ( $>>048)$ anlamlı farklılık bulunmaktadır. Ancak, p değerinin 0.05 'e çok yakın olması nedeni ile Tukey testi yapılmamıştır.

Tablo 6. Öğrencilerin derse karşı duyuşsal tutum ile ilgili durumlarının sınıf seviyelerine göre ANOVA sonuçlar

\begin{tabular}{lrrrrr}
\hline Varyansın Kaynağı & Kareler Toplamı & Sd & $\begin{array}{l}\text { Karelerin } \\
\text { Ortalaması }\end{array}$ & F & $\mathrm{p}$ \\
\hline Gruplar Arası & 3,143 & 3 & 1,048 & 2,9 &, 030 \\
Gruplar İçi & 181,836 & 520 &, 350 & 96 & \\
Toplam & 184,979 & 523 & & & \\
\hline
\end{tabular}

Tablo 6'ya göre öğrencilerin ödevin yararına ilişkin bakış açılarının internetten akademik usulsüzlük yapmaya olan eğilimlerini etkilemesinde sinıf düzeylerine göre ( $p>030)$ anlamlı farklılık bulunmaktadır. Bu farklılığın nasıl olduğunu görmek için Tablo 7'deki Tukey bulgularına bakabiliriz.

Tablo 7. Öğrencilerin derse karşı duyuşsal tutum durumu ile ilgili sınıf düzeylerine ilişkin Tukey sonuçları

\begin{tabular}{|c|c|c|c|}
\hline \multirow{2}{*}{ Fakülteler } & \multicolumn{2}{|c|}{$\mathbf{P}$} & \multirow[b]{2}{*}{2} \\
\hline & $\mathbf{N}$ & 1 & \\
\hline 1. Sinif & 164 & & 2,424 \\
\hline 2. Sinif & 137 & 2,391 & 2,391 \\
\hline 3. Sinif & 110 & 2,227 & \\
\hline 4. Sinif & 113 & 2,292 & 2,292 \\
\hline sig & & 123, & 284 \\
\hline
\end{tabular}


Tablo 7'de görüldüğü gibi öğrencilerin verilen ödev ve projelere karşı tutumlarının akademik usulsüzlük davranışlarına etkisinde sınıf düzeylerine göre çıkan istatistiksel olarak anlamlı fark birinci sınıflar ve üçüncü sınıflar arasındadır. Bulgular incelendiğinde üniversite birinci sınıfta öğrenimini sürdüren öğrenciler verilen ödevin veya projenin yararına inanmadıklarında veya dersi sevmediklerinde diğer sinıf düzeylerine göre daha fazla internetten aşırma yapma eğilimi içerisindedirler. üçüncü Sınıf öğrencileri ise ödevin yararına inanmasalar da, dersi sevmeseler de diğer sınıf düzeylerine göre daha az aşırma yapmaya yönelmektedirler. Ancak, henüz daha üniversite eğitiminin başında olan üniversite öğrencilerinin diğer sınıf düzeylerine göre ödevin yararına inanmadıklarında daha fazla aşırma yapma eğilimi içinde olmaları dikkat çeken bir bulgudur. Bu bulgu da Albers- Miller vd. (2000) yaş ile akademik usulsüzlük arasında ters ilişki bulunduğunu belirttiği araştırma ile paralellik göstermektedir. Yaş arttıkça akademik usulsüzlük oranı azalmaktadır.

\section{Üçüncü Araştırma Sorusu İle İlgili Bulgular ve Yorumlar}

Tablo 8. Zaman yönetimi

\begin{tabular}{|c|c|c|c|c|c|c|}
\hline Sorular ve Faktörler & \multicolumn{2}{|c|}{ Katıliyorum } & \multicolumn{2}{|c|}{ NKNK } & \multicolumn{2}{|c|}{ Katılmiyorum } \\
\hline Faktör 3: Zaman Yönetimi & $f$ & $\%$ & $f$ & $\%$ & $f$ & $\%$ \\
\hline $\begin{array}{l}9 \text { Kopyala- Yapıştır yaparak } \\
\text { Ödev/Proje hazırlamak bana zaman } \\
\text { kazandırıyor. }\end{array}$ & 297 & 56,7 & 192 & 36,6 & 35 & 6,7 \\
\hline $\begin{array}{l}10 \text { İnternet ortamında aynısı hazır } \\
\text { bulunan bir ödev için tekrardan } \\
\text { uğraşmak anlamsız oluyor }\end{array}$ & 171 & 32,6 & 188 & 35,9 & 165 & 31,5 \\
\hline $\begin{array}{l}11 \text { Teslim tarihine yakın ödev } \\
\text { yapmaya başlıyorum ve } \\
\text { yetiştirememe telaşı ile kopyala- } \\
\text { yapıştır başvuruyorum. }\end{array}$ & 215 & 41,0 & 205 & 39,1 & 104 & 19,8 \\
\hline Genel Ortalama & & 43,4 & & 37,2 & & 19,3 \\
\hline
\end{tabular}

*NKNK: Ne katıliyorum ne katılmıorum

Tablo 8'deki bulgular incelendiğinde bilgisayarın teknik özelliklerini ve internetin hazır bilgi sunma özelliğini kullanarak kısa yoldan ödev/ proje ortaya çıkartabilme olanağ $(\% 56,7)$ öğrencileri internetten aşırma yapmaya en çok yönelten neden olarak ortaya çıkmıştır. Tablodaki bulgulara göre zaman yönetimini becerememe nedeni ile ödev ve projelerini erteleyerek son ana bırakan öğrenciler, ödevlerini teslim zamanına yetiştirebilmek için internetten 
kopyala yapıştır yöntemi ile aşırma yapma $(\% 41,0)$ eğilimi içinde olduklarını, zaman kazanmak için kopyala-yapıştır yaptıklarını $(\% 56,7)$ belirtmektedirler. $\mathrm{Bu}$ bulgular, öğrencilerin zaman yönetimi konusunda ciddi bir problemleri olduğunu göstermektedir. Ayrıca, araştırmaya katılan her 3 öğrenciden birinin $(\% 32,6)$ internet ortaminda aynısı bulunan ödevleri yapmayı anlamsız buldukları için kopyala-yapıştır eğilimi içinde olduklarını belirtmelerinin, üniversite öğretim elemanlarına önemli bir mesaj olduğu kanısındayız.

Bulgular öğrencilerin yanlış zaman yönetimi nedeniyle internetten aşırma yapma davranışı göstermeye eğilimleri açısından incelendiğinde, cinsiyet açısından $(p<0.413)$ istatistiksel olarak anlamlı bir farklılık bulunmadığını göstermektedir.

Tablo 9. Öğrencilerin zaman yönetimiyle ilgili durumlarının fakülteye göre ANOVA sonuçları

\begin{tabular}{lccrcc}
\hline $\begin{array}{l}\text { Varyansın } \\
\text { Kaynağı }\end{array}$ & $\begin{array}{c}\text { Kareler } \\
\text { Toplami }\end{array}$ & \multicolumn{2}{c}{$\begin{array}{c}\text { Sd Karelerin } \\
\text { Ortalamas1 }\end{array}$} & F & p \\
\hline Gruplar Aras1 & 3,759 & 6 &, 627 & 2,153 &, 046 \\
$\begin{array}{l}\text { Gruplar İçi } \\
\text { Toplam }\end{array}$ & 150,417 & 517 &, 291 & & \\
\hline
\end{tabular}

Tablo 9'da yer alan bulgular incelendiğinde öğrencilerin yanlış zaman yönetimi nedeniyle aşırma yapma davranışı göstermelerinde devam ettikleri fakülteye $(\mathrm{p}>0,046)$, göre anlamlı bir farklılık olduğu görülmektedir. Tablo $10^{\prime}$ da bu anlamlı farklılık ile ilgili ayrıntılı bulgular yer almaktadır.

Tablo 10. Öğrencilerin zaman yönetimiyle ilgili durumlarının fakülteye göre Tukey sonuçları

\begin{tabular}{l|ccc}
\hline \multicolumn{1}{c}{ Fakültteler } & \multicolumn{3}{c}{$\mathbf{P}$} \\
\cline { 2 - 4 } & $\mathbf{N}$ & $\mathbf{1}$ & $\mathbf{2}$ \\
\hline Eğitim Fakültesi & 107 & 2,193 & \\
İktisadi ve İdari Bilimler Fakültesi & 47 & 2,130 & \\
Makina Fakültesi & 95 & 2,201 & \\
Fen- Edebiyat Fakültesi & 96 & 2,312 & 2,312 \\
Kimya-Metalurji Fakültesi & 72 & 2,322 & 2,322 \\
Elektrik-Elektronik Fakültesi & 83 & 2,206 & \\
İnşaat Fakültesi & 24 & & 2,508 \\
\hline Sig & &, 459 &, 437 \\
\hline
\end{tabular}


Tablo 10' daki bulgulara göre zaman yönetiminin internetten aşırmaya itmesi ile ilgili Fen-Edebiyat, Kimya Metalürji Fakültesinin öğrencileri ile Eğitim Fakültesi, Makina Fakültesi, Elektrik- Elektronik Fakültesi ve İktisadi İdari Bilimler Fakültesi öğrencilerinin görüşleri arasında İnşaat Fakültesi öğrencilerinin aleyhine istatistiksel olarak anlamlı bir fark vardır. İnşaat Fakültesi öğrencileri yanlış zaman yönetimi nedeni ile internetten aşırma yapmaya diğer fakültedeki öğrencilere göre daha fazla eğilimlidirler. Bu bulgu söz konusu fakültede verilen ödevlerin niteliğinin ders hocaları tarafından tekrar gözden geçirilmesinde fayda olduğu mesajını vermektedir. Bulgular fakülteler bazında tek tek incelendiğinde İdari ve İktisadi Birimler'de zamanı yönetememe nedeni ile aşırma yapma eğilimi en düşük olan fakülte olduğu, Eğitim Fakültesi'nin ise en düşük ikinci sırada yer aldığı görülmektedir. Bu iki fakültenin de sosyal ağırlıklı fakülteler olmaları ve verilen ödevlerin de hesap, çizimden çok analiz düzeylerine dayalı olması dikkat çekmektedir. Belki de sosyal bilimlere dayalı fakültelerde verilen ödevlerde bu nedenlerden dolayı kopyala-yapıştır yapma olanağı daha azdır da denebilir.

Bulgular öğrencilerin yanlış zaman yönetimi nedeniyle internetten aşırma yapma davranışı göstermeye eğilimleri açısından incelendiğinde, öğrencilerin bulundukları sınıf düzeyine göre $(p<.308)$ istatistiksel olarak anlamlı bir farklılık bulunamamaktadır.

\section{Sonuç}

Araştırmanın sonuçlarına göre üniversite öğrencilerini internetten akademik usulsüzlüğe iten nedenler verilen ödevlerin niteliği, değerlendirme yöntemi, öğrencilerin derse karşı duyuşsal tutumu ve ödevlerdeki zaman yönetimi olarak cinsiyet, fakülte ve sınıf düzeyine göre istatistiksel olarak anlamlı farklılık göstermektedir. Ezbere dayalı, analiz düzeyinde olmayan ödevler öğrencilerin ödevle ilgili bilgiyi internetten bularak kopyala yapıştır yapmasına yol açan en önemli nedenlerden biri olarak ortaya çıkmıştır. Öğretim elemanlarının her yıl aynı ödev veriyor olması da, internetten eski yıllara ait ödevleri bulabilmeyi kolaylaştırmakta ve dolayısıyla öğrencilerin eski ödevler kopyalayarak teslim etmelerine yol açabilmektedir. Öğrencilerin öğretim elemanlarının ödevleri özenli bir şekilde okumadığını, sadece şekilsel olarak göz atarak notlandırdıklarını, öğrencilerini araştırmaya itecek ve öğrenmelerine katkı sunacak bir dönüt yazmadıklarını düşünmeleri internetten akademik usulsüzlüğe yönelten nedenler olarak ortaya çıkmıştır. Öğrencilerin derse karşı olan duyuşsal tutumlarının, onları internetten akademik usulsüzlüğge yönelten etkenlerden biri olduğu ortaya çıkmıştır. Öğrencilerin sevmedikleri veya işlerine yaramayacağını düşündükleri dersleri zaman kaybı olarak gördükleri 
için internetten akademik usulsüzlüğe yönelerek o dersin ödevlerine de gerekli önemi vermeme eğilimi içinde oldukları ortaya çıkmıştır. İnternet'te akademik usulsüzlüğe yönelmede erkek öğrencilerle kız öğrenciler arasında kızların lehine; 1. siniflarla 3. siniflar arasında da 3. sinifların lehine istatistiksel olarak anlamlı fark bulunması konu ile ilgili yapılan diğer araştırmalarla paralel bir sonuçtur. Bilgisayarın internetten aşırma yapmaya müsait özelliklere sahip olması, üniversite öğrencilerinin kopyala- yapıştır yöntemiyle kolaylıkla ve hızlıdan internetten ödev ve proje hazırlamalarını sağladığı için öğrenciler bu yöntemi avantaj olarak görerek zaman kazanmak adına internetten akademik usulsüzlüğe yönelmektedirler. Ancak, yaş ilerledikçe bu eğilimin azılıyor olması olgunlaşma ile açıklanabilir. Öğrencilerin büyük bir çoğunluğu ise ödevini yapmayı teslim tarihine kadar ertelediği için yetiştirememe telaşına bürünüp internetten kopyala- yapıştır ile ödev yaptıklarını belirtmişlerdir. $\mathrm{Bu}$ sonuç öğrencilerin ciddi bir zaman yönetimi sorununa sahip olduklarını göstermektedir.

Tüm bu sonuçlar üniversitelerde öğretmenlik yapan akademisyenlere önemli mesajlar vermektedir. Bu sonuçlar akademisyenleri verdikleri ödevler, dönem projeleri konusunda titiz ve özenli bir çalışma içinde olmaları gerektiğini, her yıl aynı ödevleri vermemeleri gerektiği; yaratıcı, öğrenciye gerçekten gelişmesine yardımcı olacak ödevler vermeleri gerektiği sonucuna götürmektedir. Bu tip ödevler öğrencileri internetten aşırma yapma olanağı vermeyeceği gibi onarla katkı sunduğu için öğrenciler ödevleri not ötesinde amaçlar için yapacaklardır. Ayrıca, projelerin teslimi ile ilgili zaman yönetimi daha ilköğretim yıllarından öğrencilere kazandırılması gereken bir davranıştır. $\mathrm{Bu}$ davranışı kazanmamış üniversite öğrencilerine birinci sınıftan itibaren sıkı ve istisnasız tüm öğrenciler için planlı uygulamalarla zaman yönetimi davranışı kazandırılmalıdır. İnternetten akademik usulsüzlüğün önlenmesi adına, küçük yaşlardan itibaren öğrencilere belli kazanımların edindirilmesi için internet ve etik dersi ilköğretim müfredatına eklenebilir. Bununla birlikte, ödev hazırlamada referans gösterme davranışı da ilköğretimden itibaren öğrencilere kazandırılmalıdır. 


\section{Kaynakça}

Albers-Miller, N. D., Straughan R. D. ve Prenshaw P. J. (2000). The relationship between cheating and university choice: An analysis of student perceptions". İçinde Capozzoli E.A.,Tudor R.K., and McKee D, (Ed.), Advances in Marketing, Southwestern Marketing Association, Troy State University and Kennesaw State University.

Antonio, D. L. ve Michael, W. B. (1983). Short-Term Predictive Validity of Demographic, Affective, Personal and Cognitive Variables in Relation to 2 Criterion Measures of Cheating Behaviors. Educational and Psychological Measurement, 43(2), 467-483.

Austin, M. J. ve Brown, L. D. (1999). Internet plagiarism: Devoloping strategies to curb student academic dishonesty. The Internet and Higher Education, 2(1), 21-33.

Bowers, W. J. (1964). Student dishonesty and its control in college. NewYork: Bureau of Applied Social Research, Columbia University

Davis S.F., Drinan P.F. ve Gallant T.B. (2009). Reasons for Academic Disihonesty: Situation, Disposition and Changing Times, Cheating in School: What We Know and What We can Do. USA: Wiley- Blackwell.

Ersoy, A. ve Özden, M. (2011). The views of teacher candidates regarding the role of instructor in plagiarizing from internet in their assignments. Elementary Education Online, 10(2), 608- 619.

Haines, V. J., Diekhoff, G. M., LaBeff, E. E. ve Clark, R. E. (1986). College cheating: Immaturity, lack of commitment, and the neutralizing attitude. Research in Higher Education, 25(4), 342-54.

Karim, N. S. A., Zamzuri, N. H. A. ve Nor, Y. M. (2009). Exploring the relationship between internet ethics in university students and the big five model of personality. Computers and Education, 53, 86- 93.

Kelly, J. A. ve Worrell, L. (1978) Personality characteristics, parent behaviors, and sex of the subject in relation to cheating. Journal of Research in Personality, 12(3), 179-88.

Khodaie, E., Moghadamzadeh, A. ve Salehi, K. (2011). Factors affecting the probability of academic cheating school students in Tehran. Social and Behavioral Sciences, 29, 1587- 1595.

Leming, J. S. (1980). Cheating behavior, subject variables, and components of the internal- external scale under high and low risk conditions. Journal of Educational Research, 74(2), 83- 87.

Ludeman, W. W. (1938). A study of cheating in public schools. American School Boards Journal, 96(1), 45-6. 
Okay, Ş. ve Aydoğan, E. (2010). A research on the vocational high school students' intentions of internet usage. Selçuk Üniversitesi Sosyal Bilimler Dergisi, 23, 283-296.

Prenshaw, P. J., Straughan R. D., ve Albers-Miller N.D. (2001). university academic dishonesty policy and student perceptions of cheating: an exploratory content analysis across fourteen universities, advances in marketing, James L. Thomas, eds., Jacksonville, AL: Association of Collegiate Marketing Educators, 203-208.

Renard, L. (2000). Cut and paste 101: Plagiarism and the net, Educational Leadership. 57(4): 38- 42.

Roig, M. (2006). On the causes of academic dishonesty. The Journal of the European Medical Writers Association,15(4).

Roskens, R. W. ve Dizney, H. F. (1966). A study of unethical academic behavior in high school and college. Journal of Educational Research. 59(5), 231- 234

Selwyn, N. (2008). An investigation of differences in undergraduates' academic use of the internet. Active Learning in Higher Education, 9(11), 11-22.

Ward, D. A. ve Beck, W. L. (1990). Gender and dishonesty. The Journal of Social Psychology, 130(3), 333-339. 